\title{
The effect of Mistral (a strong NW wind) episodes on the occurrence and abundance of Atlantic bluefin tuna (Thunnus thynnus) in the trap fishery of Sardinia (W Mediterranean)
}

\author{
PIERO ADDIS, MARCO SECCI and ANGELO CAU \\ University of Cagliari, Department of Life Science and Environment, Via Fiorelli 1, 09126 Cagliari, Italy. \\ E-mail: addisp@unica.it
}

\begin{abstract}
SUMMARY: From April to June Atlantic bluefin tuna, Thunnus thynnus, migrate along the western Sardinian coastline in a southward direction, where they are intercepted by the trap fishery. Fishermen claim that Mistral episodes facilitate the entry of tuna schools towards the traps, thus increasing capture rates. To test the fishermen's hypothesis we conducted underwater visual counts of tuna in the trap chambers and analysed these data under the effect of wind. The results indicate a "stair-step" pattern in the abundance of tuna, demonstrating that major increases in abundance are associated with the Mistral. The second analytical approach involved a longer time scale to test whether higher Mistral occurrences corresponded to periods when higher captures were recorded. Using a linear regression model we found a significant correlation $(\mathrm{p}<0.01)$ between catches and the wind speed class $\leq 15$ knots. We hypothesize that the wind-driven current may produce favourable conditions for tuna migration and could play a significant role in enabling fish to save energy. It was also noted that the wind speed class $>15$ knots seemed to have a negative effect on captures. This pattern may be caused by wind-induced advection of coastal waters generating a physical boundary that may have had a deterrent effect on tuna schools.
\end{abstract}

Keywords: Thunnus thynnus, trap fishery, abundance, visual census, wind effect, Western Mediterranean.

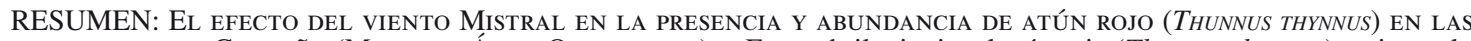
almadrabas de Cerdeña (Mediterráneo Occidental). - Entre abril y junio, el atún rojo (Thunnus thynnus) emigra a lo largo de la costa oeste de Cerdeña en dirección suroeste, donde es interceptado por las almadrabas locales. Los pescadores afirman que los fuertes vientos del Noroeste (Mistral) facilitan la entrada de los bancos hacia las almadrabas incrementando las capturas. Para verificar la hipótesis de los pescadores se han contado los ejemplares de atún mediante observaciones subacuáticas y se han puesto en relación a los datos de viento recogidos en la zona. Los resultados muestran un modelo de incremento "escalonado" de abundancia en la almadraba, cuyos valores más altos corresponden a los vientos más fuertes. Para probar si los años con mayor número de días con vientos del NO se corresponden con mayor número de capturas, hemos hecho un segundo enfoque del análisis que utiliza una escala de tiempo más amplia. Mediante un modelo de regresión lineal encontramos una correlación positiva significativa $(\mathrm{p}<0.01)$ entre las capturas y la clase de vientos $\leq 15$ nudos. Sin embargo, la clase de vientos $>15$ nudos parece tener un efecto negativo en las capturas. Una posible explicación que encontramos es que la advección de aguas costeras, provocada por el viento, genera una barrera física en el área de la almadraba, manteniendo los bancos alejados.

Palabras clave: Thunnus thynnus, almadrabas, abundancia, observaciones subacuáticas, viento, Mediterráneo occidental.

\section{INTRODUCTION}

The Atlantic bluefin tuna, Thunnus thynnus (BFT) is one of the world's most important fishing resources.
It has long been a significant food supply for many coastal communities and has become an integral part of the globalized fish market. This species is a large toppredator fish which inhabits the pelagic ecosystems of 
the North Atlantic Ocean and the Mediterranean Sea. Much like other large tunas, the BFT is a migratory species, with documented transoceanic and large-scale movements for feeding and reproduction (Rooker et al. 2008). Currently the international scientific community recognizes the existence of two BFT population "ecotypes", corresponding to two major reproductive areas for the species: Gulf of Mexico and the Mediterranean Sea. This hypothesis also justifies the two-stock premise ("western" and "eastern" populations) adopted by the International Commission for the Conservation of the Atlantic Tunas (ICCAT) for the purposes of management policy development. However, because of the complex interplay of ecological, behavioural and reproductive factors and uncertainties in their genetic differentiation, the spatial structure of BFT and the degree of separation between the two "separate" stocks remains as yet unclear (Viñas et al. 2010).

The Mediterranean Sea is a semi-enclosed system consisting of two partly isolated basins which provide a full suite of seasonal options for the reproductive and foraging processes of BFT. An innate migration strategy guides this species through this basin, where spawning site fidelity and natal homing have been widely documented by electronic tagging data (Block et al. 2005, De Metrio et al. 2005, Medina et al. 2011, Tudela et al. 2011), the microchemistry of otoliths (Rooker et al. 2008), historical records (Doumenge 1998) and studies in population genetics (Carlsson et al. 2004, Riccioni et al. 2010).

In the coastal areas of the Mediterranean and the eastern Atlantic, adult BFT are still captured by traditional trap fisheries during both the pre- and post-spawning migration (Medina et al. 2002). Such gears (tonnara in Italian) can be useful for designing quantitative experimental studies designed to test specific hypotheses, such as when information is sought regarding migration patterns related to surface circulation during their approach to coastal waters (Lemos and Gomes 2004, Ravier and Fromentin 2004, Addis et al. 2008). The use of observation traps for studies of BFT ecology is relatively well documented thanks to extensive previous research on this topic. Chance but recorded observations from the past have been of great value in terms of understanding relationships between the variability of tuna catches and the environment (Neuparth 1923, De Buen 1925, Sella 1929, Lozano Cabo 1958, Rodriguez-Roda 1964, Sarà 1980). However, these studies often lacked a sound scientific basis and frequently failed to test assumed hypotheses. Recently, complex relationships between BFT stock and various abiotic and biotic factors have been investigated using time-series analysis of trap data, particularly by means of smoothing methods and autoregressive models (Fromentin et al. 2000, Ravier and Fromentin 2004, Addis et al. 2008).

Using smaller temporal and spatial scales, Lemos and Gomes (2004) investigated the effects of local oceanographic conditions on the occurrence of BFT in coastal waters where traps are located. Based on infor- mation related to daily trap catches, these authors acquired information that enhanced the understanding of the entry patterns of tuna schools in a Portuguese trap. They also pointed out the difficulties associated with the application of regression models to studies (which rely on zero-inflated data) such as daily trap catches following a mattanza (the last phase of fishing). Indeed, because the mattanza may occur for several days after the entry of fish into the trap chambers, it is difficult to relate data from the mattanza to corresponding environmental conditions, since they do not always match. Such problems can only be avoided by simultaneous direct observations of BFT entering the trap system, combined with records of environmental conditions such as daily underwater visual counts of individuals.

Sardinia (western Mediterranean) is geographically included in the reproductive migration pathways of BFT. Tuna schools migrate along the western coastline in a southward direction, swimming closer to the bathymetric contour of $40 \mathrm{~m}$, where they have for centuries been intercepted by the local trap fishery (Angotzi 1901). This fishery is the only remaining trap in the Mediterranean that provides valuable scientific information about the status of the bluefin tuna population (Addis et al. 2012, ICCAT, 2012). This ancient method of fishing has today reached a critical phase, because it is now close to disappearing altogether (other traps still active are located in the eastern Atlantic, in Portugal, Spain and Morocco).

During a long-term monitoring programme $(1991 \rightarrow)$ of the tuna trap fishery of Sardinia, we had the opportunity to work beside the trap fishermen to investigate diverse aspects of the ecology of BFT (Addis et al. 2012). For instance, we have often had occasion to contest and query the trap fishermen's (tonnaroti) claim that "the occurrence and abundance of bluefin tuna in the trap chambers are affected by the strong wind from the northwest (the Mistral) because it helps to transport them along their path and thus towards the entrance of the trap".

The purpose of this study was to test the fishermen's hypothesis. To meet this objective we used two separate time-scale analyses: a short time scale based on daily underwater visual counts of bluefin tuna in the trap chambers matched with daily wind data, and a longer-term scale that made use of records obtained from historical trap captures and wind statistics.

\section{MATERIALS AND METHODS}

\section{Study area and trap description}

The study area is in southwest Sardinia (Italy) (Fig. 1). Since the sixteenth century, bluefin tuna traps have been used at two locations: Isola Piana and Portoscuso. These traps are classified as "tonnara di corsa" (tuna on the path) because tuna are captured during the pre-spawning migration and trapped specimens are characterized by having ripening gonads. Our investi- 
gation was conducted at the Isola Piana trap, located at $39^{\circ} 11^{\prime} \mathrm{N}$ and $08^{\circ} 17^{\prime} \mathrm{E}$. The gear consisted of nylon nets arranged in a tail $(1050 \mathrm{~m})$ and five chambers, known as the grande $(120 \times 45 \mathrm{~m})$, the bordonaro $(45 \times 45 \mathrm{~m})$, the bastardo $(45 \times 40 \mathrm{~m})$, the camera di ponente $(45 \times 40$ $\mathrm{m})$ and the camera della morte (the "death chamber") $(45 \times 30 \mathrm{~m})$. Only the death chamber has a net mesh "floor" that is used to draw up the BFT during the mattanza. The series of chambers together form what is known as the "castle", while the tail is perpendicular to the trap and almost reaches the coastline. The trap is deployed at depths ranging from $10 \mathrm{~m}$ (at the end of the tail) to $42 \mathrm{~m}$ (at the "castle"). Tuna enter the trap swimming naturally until they reach the "tail" and cross into the "trap mouth". Once inside they are initially enclosed in the largest chamber, the grande, and then cross from east to west into the other four chambers through the narrow passages, which form a system of man-operated moving nets.

\section{Meteorological data}

Wind data were collected from the automatic Data Collection Platform weather station at Carloforte (39 $08^{\prime} \mathrm{N}$; $08^{\circ} 19^{\prime} \mathrm{E}$ ) at a distance of $4 \mathrm{~km}$ from the trap location (Fig. 1). This is one of the reference weather stations operated by the Italian Air Force's Meteorological Service since 1940, established in 1899 by the International Astronomical Union. The weather station is located in an open and flat area $15 \mathrm{~m}$ above sea level, representing a full reference for all winds which hit the island of San Pietro.

Wind data (direction and speed in knots) refer to daily recordings in the period April-June 2009 and 2010 and 1969-2005. They were treated in different ways according to the two approaches described in the following sections.

\section{Short-term analysis}

The aim of the short-term analysis was to identify i) the pattern of occurrence and abundance of BFT in the trap chambers and ii) the expected relationship of abundances with wind conditions.

\section{Pattern of occurrence and abundance of BFT}

For the first objective, during the period April-June 2010, we carried out daily underwater visual counts of BFT. Visual counts were carried out independently but simultaneously by two professional SCUBA divers during daylight hours between 7 and 9 a.m. This inspection was part of a daily practice used by trap divers for the following purposes: a) to control the presence/absence and the number of BFT in order to schedule fishing operations for the mattanza, so as to pull the BFT out from the death chamber; b) to control the presence/absence of entangled BFT, swordfish and/or other commercial species; c) to check the general condition of the gear,

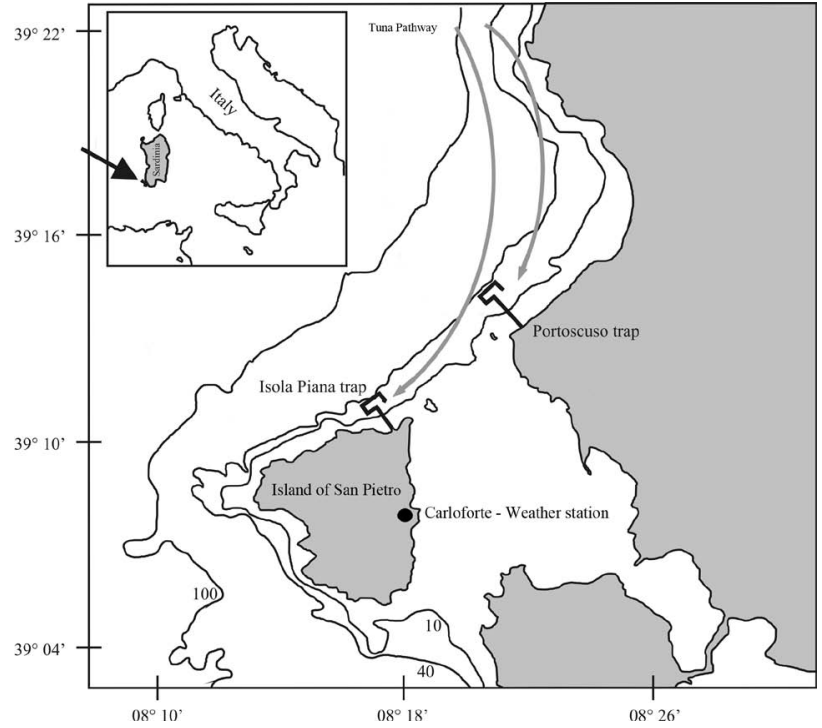

FIG. 1. - Location of the study area and pathways where bluefin tuna are intercepted by the trap fishery in southwestern Sardinia (W Mediterranean). The present investigation was conducted at the Isola Piana trap. The village of Carloforte hosts the weather station of the Italian Air Force's Meteorological Service, where meteorological data were acquired.

specifically checking for damage to the nets, the steelropes and buoys; and d) to check for presence/absence of by-catch species such as elasmobranchs (mainly sharks) that create a disturbance in the behaviour of the bluefin inside the trap chambers (Storai et al. 2011). The visual censuses carried out by the divers involved swimming slowly through the chambers in an east-to-west direction from the grande to the camera. Specimens were counted and data were recorded on a Plexiglas ${ }^{\circledR}$ board. To obtain a better estimation of the visual counts, video recordings were conducted using a 3 CCD digital camera (Sony TRV 900) protected in an underwater casing (Gates, San Diego $\mathrm{Ca}$ ). Video tapes were reviewed in slow motion or stop-frame mode to identify and count the fish from each sampling session.

The accuracy of visual counts was evaluated by plotting the number of specimens captured during each mattanza (M) vs the number of visual counts taken before and after the mattanza $\left(\Delta \mathrm{V}_{\mathrm{ba}}\right)$. The assumption is that if the two counts perfectly match (i.e. $M=\Delta V_{b a}$ ), the expected values should be represented by a perfect diagonal (bisector) starting at zero. The slope of the fitted line from observed data was tested by F-test under the null hypothesis $\mathrm{H}_{0}: \mathrm{b}=0(\alpha=0.05)$. Otherwise, if $\mathrm{H}_{0}$ is rejected, there is a linear relationship between the two variables. In this case the relationship found is useful to correct the entire visual count dataset.

The recalculated data were subsequently plotted by day to provide a graphical representation of the pattern of abundance of specimens in the trap chambers. Data were also compared with the estimated number of tuna (as they occur randomly inside the trap) by calculating the mean number of tuna by day. Differences between distributions were analysed by the $\chi^{2}$ test. 
TABLE 1. - Description of the data sets used in the analysis.

\begin{tabular}{llcll}
\hline Variable & \multicolumn{1}{c}{ Period } & $\mathrm{n}$ & \multicolumn{1}{c}{ Remarks } & \multicolumn{1}{c}{ Source } \\
\hline \multirow{2}{*}{ Visual count } & May 4-13, 2009 & 850 & Number of BFT counted by day & Underwater visual counts \\
& May 27-29, 2009 & 270 & & \\
Catch & April 20-June 28, 2010 & 4597 & & \\
Wind & 1969-2005 & 16124 & Number of BFT captured by month & Trap company archives \\
& 2009-2010 (April-May-June) & 140 & Daily wind speed and direction & Weather Station Carloforte \\
\hline
\end{tabular}

\section{Relationship of abundances with wind data}

For the second objective, daily visual counts were matched with concurrent wind data and properly analysed. Visual counts referred to those of 2010 described above and an additional dataset of visual counts carried out in May 2009 (Table 1). An experimental beforeafter design was applied to test whether the occurrence of strong Mistral wind events was involved in the increased catches of BFT inside the trap chambers. The time split associated with the "before" and "after" wind perturbation were chosen on the basis of daily wind statistics. Wind data were analysed by bubble chart, in which the $x$ axis indicates time (days and months) and the $y$ axis indicates the wind classes by quadrant. The bubble represents a third factor related to the wind intensity, represented by the dimension of the bubble. Plots enabled us to identify the occurrence of strong wind events by direction and thus to separate visual count data "before" and "after" Mistral wind. One-way analysis of variance was performed using the modelled set of data to verify the effects of wind on BFT abundances. The software package STATISTICA 7.0 (StatSoft, Inc.) was used to perform ANOVA.

\section{Long-term analysis}

The second analytical approach made use of a longer time scale to test whether years with a greater number of Mistral-days corresponded to higher tuna captures. To this end we examined a historical time series of captures (number of BFT) recorded in the private archives of the trap company and wind data from the period 1969 to 2005 (Table 1). Catch data were considered by year (C) and separated monthly, considering captures in May $\left(\mathrm{C}_{5}\right)$ and June $\left(\mathrm{C}_{6}\right)$. Wind data included the number of days per year with wind intensity $\leq 15$ knots $(\mathrm{L})$ and by months $\left(\mathrm{L}_{5}\right.$ and $\left.\mathrm{L}_{6}\right)$ and the number of days per year with intensity $>15$ knots $(\mathrm{H})$ and by month $\left(\mathrm{H}_{5}\right.$ and $\left.\mathrm{H}_{6}\right)$ for the same time series. The use of these wind speed classes was suggested by a preliminary stepwise analysis in which a persistence longer than five days for speed intensity $>15$ knots was identified.

\section{Relationships: catch vs wind data}

Possible correlations were initially analysed using graphical data exploration by scatterplot matrix, applying Pearson's test to verify the null hypothesis of independence between catch and wind data. The correlation coefficient of Pearson's test ( $r$ ) can vary from +1 (direct association) to -1 (indirect association) when the correlation is highest to values close to 0 , indicating an absence of any correlation. Where an association was found, a generalized linear model (GLM) (McCullagh and Nelder 1989) was applied to explain the variation in the captures as a function of wind intensity. The general linear model applied was $C_{i}=\alpha+\beta W_{j}+e_{j k}$, where $\alpha$ is the intercept, $\beta$ is the population slope, $\mathrm{W}$ is the effect of wind intensity at low (L) and high intensity $(\mathrm{H})$ and $\mathrm{e}_{\mathrm{jk}}$ is the error term. We assumed a negative binomial error distribution with log-link function $(\alpha=0.01)$. Data were processed using the Brodgar v. 2.6.6 software package (http://www.brodgar.com).

\section{RESULTS}

\section{Short-term analysis}

The effectiveness of visual counts of the BFT inside the trap chambers is illustrated in Figure 2. Results of the F-test rejected the null hypothesis $\mathrm{H}_{0}$ $(\mathrm{P}>0.05)$, revealing a linear relationship between $\Delta \mathrm{V}_{\text {ba }}$ and $M$. The effective number of bluefin tuna counts was recalculated using the relationship $\Delta \mathrm{V}_{\mathrm{ba}}=0.7922$ $\mathrm{M}\left(\mathrm{r}^{2}=0.73\right)$.

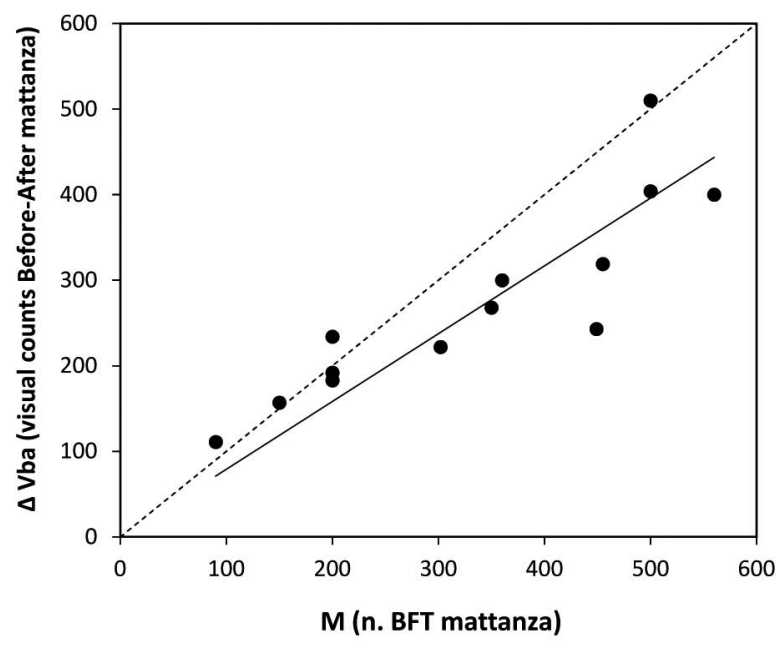

FIG. 2. - Scatterplot between the number of specimens captured during each mattanza $(\mathrm{M})$ and the number of visual counts taken before and after the mattanza $\left(\Delta \mathrm{V}_{\mathrm{ba}}\right)$. The expected value is represented by the dotted line (i.e. the bisector) corresponding to $M=\Delta V_{b a}$; the straight line is the fitted regression curve from observed data $\left(\Delta \mathrm{V}_{\mathrm{ba}}=0.7922 * \mathrm{M} ; \mathrm{r}^{2}=0.73\right)$ 


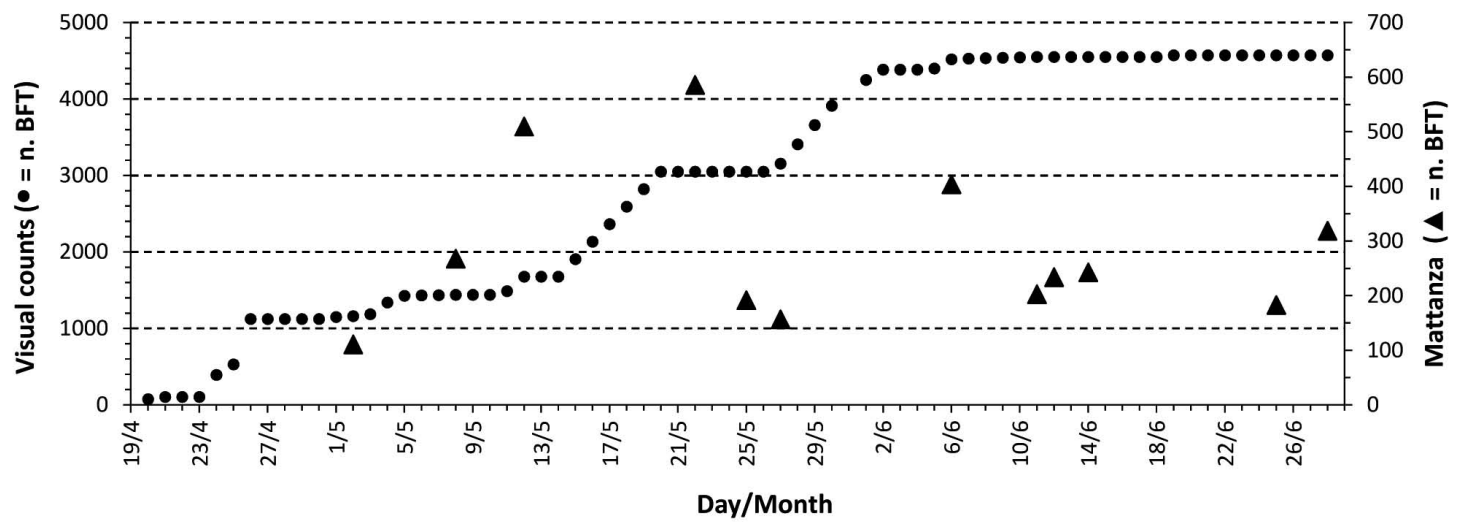

Fig. 3. - Plot representing the cumulative number of bluefin tuna in the time range April 20-June 28, 2010 (Visual counts, $\bullet$; Mattanza, $\mathbf{\Delta}$ ). Data from visual counts have been recalculated using a correction factor derived from the relationship between expected and observed values. The number of specimens caught by mattanza was added to the number of bluefin tuna estimated by visual counts on the corresponding day.

The new data were plotted to provide a graphical representation of the pattern of occurrence and abundance of specimens in the period April-June 2010 (Fig. 3). We observed that during the first eight days of visual counts the number of specimens increased exponentially. The earliest arrivals of BFT entered the trap chambers on April 20, forming a small school of 60 specimens of a roughly homogeneous size (data not presented here). Four days later (on April 24) the number had increased to 300 individuals. A stable plateau or "step" was reached by April 26 and this remained constant until May 2 when the first mattanza occurred. Since this trend is confounded by the mattanza, which resulted in declines in the occurrence of BFT and a consequent oscillating pattern of visual count data, we visualized the total number of individuals, i.e. the number of BFT captured by mattanza as well as the number estimated through visual counts (Fig. 3). A detailed analysis of the cumulative plot revealed a "step" pattern with four increments and five steps. An absolute peak was reached on June 25 near the end of the fishing season, when a total of
4597 specimens were counted inside the trap chambers. The number of expected BFT was estimated to be 66.6 specimens/day. A $\chi^{2}$ comparison between observed and expected distributions indicated a statistically significant difference $(p<0.05)$.

For the study of expected relationship with wind statistics, we initially conducted a graphical data exploration. The analysis on wind classes and speed from April 20 to the end of June 2010 highlights the prevalence of the NW wind, which occurred for 32 of the 71 days analysed (mean speed $=11 \pm 3.2$ knots). This was followed by SE, which occurred in 25 out of 71 days (mean speed $=5.8 \pm 1.2$ knots). Calm days occurred on 9 of the 71 days. An analysis of the bubble plot identified three significant strong NW wind events in 2010 (Fig. 4). The earliest event started on 15 May and lasted for five days (mean speed $=7.6 \pm 2.6$ knots, $\max$ speed=17.1 knots); the second and the third started on 30 May (mean speed $=5.3 \pm 2.6$ knots, max speed $=20.3$ knots) and 19 June (mean speed=5.2 \pm 2.4 knots, $\max$ speed $=17.3$ knots), respectively, each with a total duration of five days.

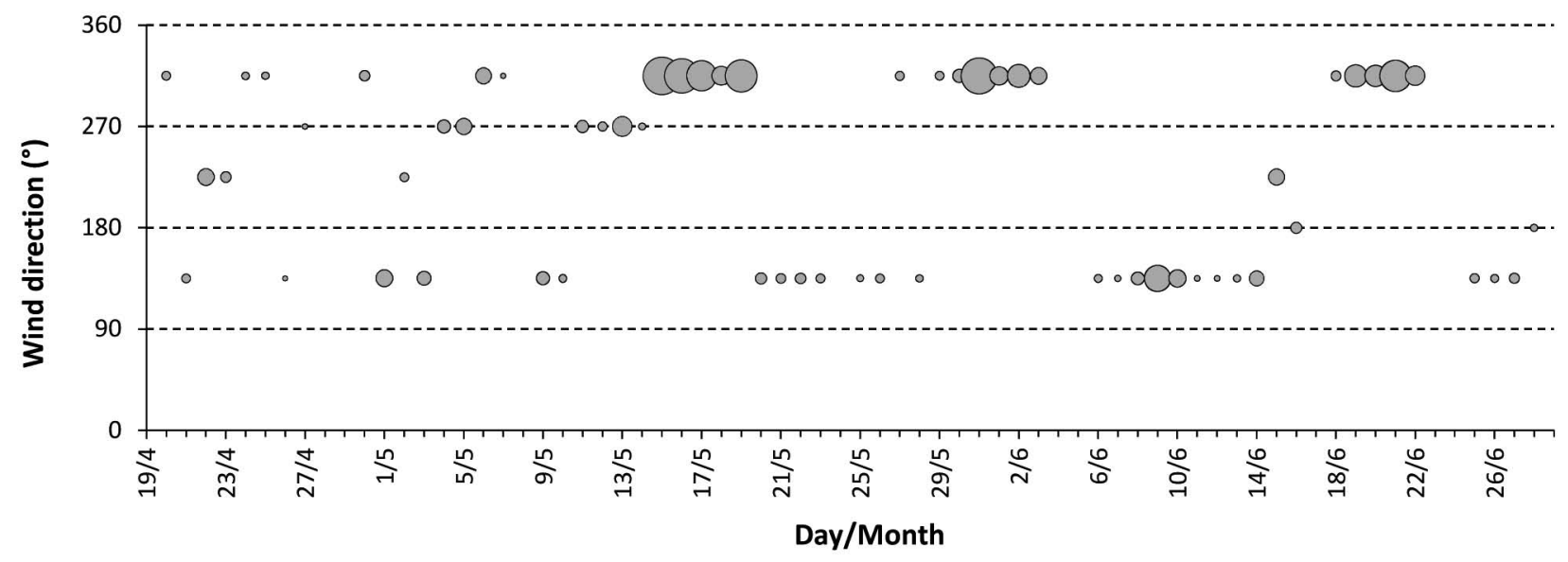

FIG. 4. - Bubble plot representing the wind statistics by quadrant during 2010. The dimension of bubbles is related to the wind intensity. The plot highlights three significant strong Mistral events (wind classes between $270^{\circ}$ and $360^{\circ}$ ) used for the short-term analysis. 


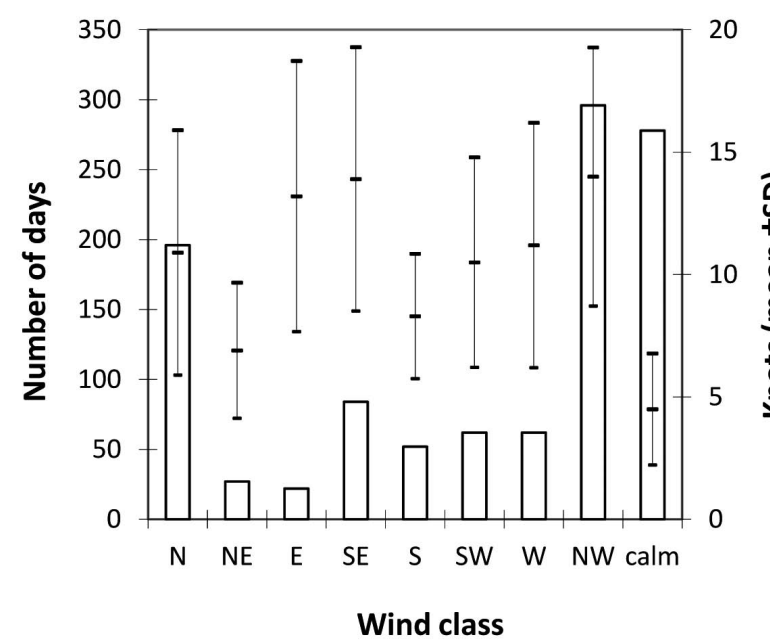

FIG. 5. - Bar graph reporting the wind statistics (number of days by wind classes) for the period May to June 1969-2005 used in the long-term analysis (years $=36$; valid years $=25$ ). Whiskers represents the wind speed variability in knots (mean $\pm \mathrm{SD})$. A prevalence of wind classes belonging to the $4^{\text {th }}$ quadrant ( $\mathrm{NW}$ and $\mathrm{N}$ ) is evident.

In 2009, we recorded three significant strong NW events, the earliest on April 27-May 1 (mean speed $=8.3 \pm 1.7$ knots, $\max$ speed $=21$ knots), followed by another on May 12-14 (mean speed=6.7 \pm 3.2 knots, max speed=18.5 knots). Finally, on May 27-29, there was another significant strong wind event (mean speed $=5.9 \pm 2.7$ knots, max speed $=21.3$ knots ).

The ANOVA test used to analyse visual counts associated with the wind condition highlighted a significant difference $(p=0.0095)$ in BFT counts between "before" and "after" the Mistral events.

\section{Long-term analysis}

Results of the wind data analysis by speed and quadrant for the period 1969-2005 highlighted the prevalence of NW and $\mathrm{N}$ wind classes, although there were also a large number of days with calm winds. Descriptive analysis is represented here with a bar graph (Fig. 5) including a second axis that indicates wind speed (knots \pm sd). This analysis is useful for extracting data on prevailing Mistral wind conditions.

Based on the initial hypothesis, we expected to find a linear regression between the number of windy days per year and BFT captures. The explorative data analysis was conducted first by scatterplot matrix between variables (Fig. 6). We considered total catch $(\mathrm{C})$, catches in May $\left(\mathrm{C}_{5}\right)$ and June $\left(\mathrm{C}_{6}\right)$, and the explorative variables of the number of 'low wind intensity days' per year (L) and per month $\left(\mathrm{L}_{5}\right.$ and $\left.\mathrm{L}_{6}\right)$ against high wind intensity days per year $(\mathrm{H})$ and per month $\left(\mathrm{H}_{5}\right.$ and $\left.\mathrm{H}_{6}\right)$. The first three rows and columns of the plot indicate catches, while the others indicate the variables for wind intensities, including Pearson's correlation coefficient in the lower diagonal part of the graph.

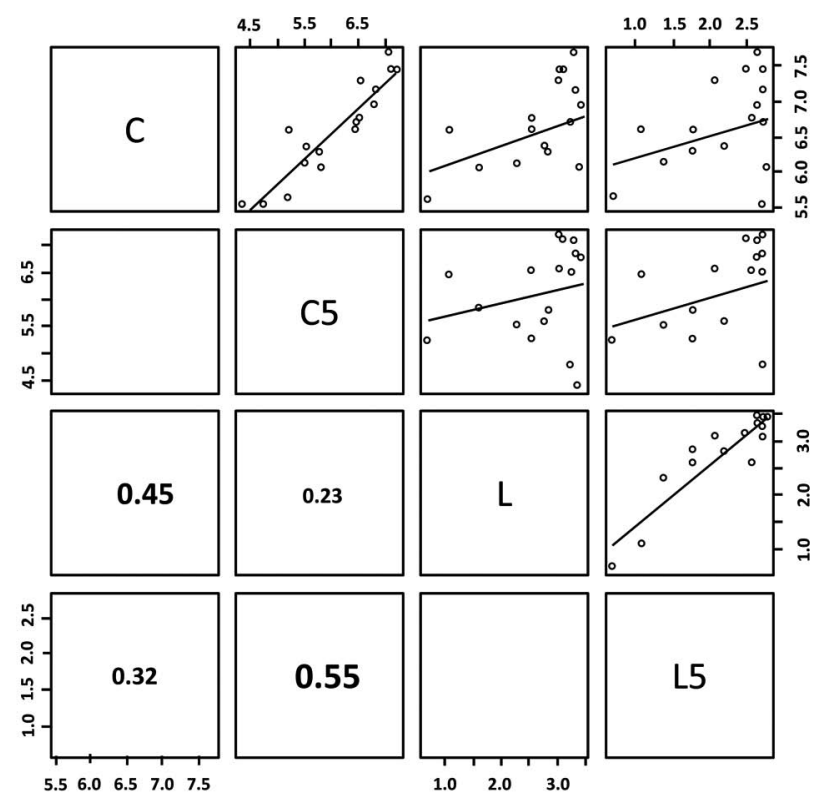

FIG. 6. - Scatterplot matrix for the response variable catch considered by year $(\mathrm{C})$, May $\left(\mathrm{C}_{5}\right)$ and two selected explanatory variables for wind speed data: $\leq 15$ knots (L), by month (L5). The upper diagonal panels show the pair-wise scatterplots including a straight line. The lower diagonal boxes contain the absolute correlations coefficients of Pearson's test (r). The pairplot indicates a clear linear relationship between $\mathrm{C} 5 \times \mathrm{L} 5(\mathrm{r}=0.55)$ and a lesser one between $\mathrm{C} \times \mathrm{L}$ $(\mathrm{r}=0.45)$

Analysis of the various cross combinations indicates a positive correlation between $\mathrm{C}_{5}$ and $\mathrm{L}_{5}$ and $\mathrm{C}$ and $\mathrm{L}$, with Pearson's coefficient values of $r=0.55$ and $r=0.45$, respectively. The application of GLM provides a significant effect of the 'low speed' NW wind in May $\left(\mathrm{L}_{5}\right)$ on bluefin tuna catches in May $\left(\mathrm{C}_{5}\right)$ (Table 2). In contrast, no significant effect (at the $1 \%$ level of significance) was observed in the interaction between the whole catches $(C)$ and the low wind intensity (L) $(p=0.045)$.

Analysis of other plots indicate a negative relationship between total catches (C) and high wind intensity (H). Similar relationships seem to exist between $\mathrm{C}_{5}$ and $\mathrm{H}_{5}$ and $\mathrm{C}_{6}$ and $\mathrm{H}_{6}$. The inspection of these plots gave no immediate indications of collinearity between the response and explanatory variables, also confirmed by the low Pearson's coefficient for all the combinations: $\mathrm{C}_{*} \mathrm{H}(\mathrm{r}=0.20), \mathrm{C}_{5 *} \mathrm{H}_{5}(\mathrm{r}=0.10)$ and $\mathrm{C}_{6 *} \mathrm{H}_{6}(\mathrm{r}=0.16) . \mathrm{In}$ this instance, we omitted the above variables for the further analysis by GLM.

TABLE 2. - Results of GLM for the total catch (May and June cumulated) and for May (below), under the effect of Mistral wind with the intensity $\leq 15$ knots.

\begin{tabular}{|c|c|c|c|c|}
\hline Source & Estimate & Std. Error & $t$-value & $p$-value \\
\hline & & & & \\
\hline & 0.029 & 0.015 & 2.00 & 0.045 \\
\hline \multicolumn{5}{|c|}{ Null deviance 22.22; Residual deviance 18.98; AIC 275.9} \\
\hline & & & & \\
\hline & 0.10 & 0.023 & 4.38 & $<0.001$ \\
\hline \multicolumn{5}{|c|}{ Null deviance 33.21 ; Residual deviance 15.4 ; AIC 214.38} \\
\hline
\end{tabular}




\section{DISCUSSION}

We attempted to verify the "fisherman's hypothesis" that the Mistral wind affects the occurrence and the abundance of bluefin tuna in a trap fishery in Sardinia.

In the first approach we statistically verified the interaction between wind conditions and visual counts. We also noted a significant increase in the number of BFT during the "after" period associated with the Mistral. The pattern of occurrence of BFT in the trap system was found to follow a "stair-step" model, in which the major step rises were shown to be a consequence of the NW wind episodes.

In the second approach, our results confirmed previous analysis, but only at the lower wind speed classes. We have strong reservations regarding the situation associated with high wind speed classes, since the process seemed to be affected by negative feedback. Specifically, we found a positive correlation between the number of years with "low" speed class wind events, namely wind from the NW up to 15 knots, and trap catches. However, when the "high" speed class (greater than 15 knots) was considered, we noted that catches actually decreased. To better explain how the wind variability can affect the migratory behaviour of BFT, we need to speculate on the surface circulation conditions in the area studied and their relationships with the ecology of bluefin tuna. Oceanographic studies from western Sardinia revealed that the hydrodynamic processes in the area are mainly driven by the circulation of the AlgeroProvencal Algerian Basin (Pinardi and Masetti 2000, Sorgente et al. 2003, Ribotti et al. 2004, Schneider et al. 2005). This coast is affected by anticyclonic mesoscale eddies of about $100 \mathrm{~km}$ in diameter, which are responsible for the mainly southward-moving coastal surface current (Robinson et al. 2001). Moreover, in western Sardinia the variability of the surface circulation is strongly affected by meteorological forcing, i.e. the wind-driven circulation originating from westerly winds leads to surface currents that strongly affect the Sardinian coast. Wave data indicate that waves generated by the Mistral wind are dominant and $75 \%$ of the largest storms arrive from this direction $\left(300^{\circ} \mathrm{N}\right)$ and typically occur during winter and spring (Donda et al. 2008).

We hypothesize that the wind-driven current, in a southward direction, may produce favourable conditions for tuna migration and could play a significant role in enabling fish to save energy that would normally be used for swimming.

It is well known that the reproductive migration of $\mathrm{BFT}$ is an energetically intensive process that requires a large accumulation of energy throughout the year and that specimens therefore tend to minimize energy expenditure during such migrations (Chapman et al. 2011). In the Mediterranean, spawning occurs in MayJune, soon after the period when net energy intake is at its lowest level. Individuals also face the problem of limited additional energy supply, because feeding dur- ing reproductive migration and spawning is generally sporadic (Mather et al. 1995). These results concur with our direct observations of stomachs from BFT captured in traps. Korsmeyer and Dewar (2001) also noted that there are phases when metabolic costs are scaled according to the time required for travel towards spawning grounds and the physical effort required for fish movement through the water. Intermittent swimming behaviour (between active swimming countercurrent and passive drifting swim) is therefore most likely an opportunistic strategy exploited by the species during migration so as to minimize energy expenditure. A similar mechanism has been found in young Atlantic salmon that, during the coastal migration, are assisted by wind-driven surface currents (Sloman et al. 2006) and in the swimming behaviour in the winter-migrating roach (Brodersen et al. 2008).

There is a paucity of such information in the literature, and this behaviour is often referred to in terms of wind-induced processes related to food web dynamics. This occurs in the Pacific, where wind activates the pelagic food web, generating a type of fertilizing action (Botsford et al. 2003, Rykaczewski and Chekley 2008).

To explain the negative effect on captures detected by the high speed class (i.e. Mistral wind greater than 15 knots), we proposed two possible scenarios affecting this process. First, we hypothesized that strong and persistent Mistral (longer than 5-6 days) may affect the abiotic environment, resulting in low "habitat fitness" for the BFT schools approaching the coast. According to Millot (1999), the euphotic zone of western Sardinia is strongly influenced by wind-induced advection of coastal waters. Indeed, an upwelling was identified during persistent winds from the west and northwest, which had persisted over at least five days (Millot 1999, Ribotti et al. 2004). This upwelling reduced the salinity from a depth of 30-40 m to the surface (the bathymetry range where the trap array is deployed) and caused salinity levels to decrease near the coast in comparison with the levels measured further offshore. This decrease results in the formation of a physical boundary zone in the surrounding trap area, which could keep tuna schools away, therefore reducing tuna occurrence inside the trap array. A similar pattern, affecting trap fisheries on the southern Portuguese coast, was described by Brito (1943) and Santos (1989), who found that certain winds bring sediments from land and produce turbid currents. Mazzarelli (1917) reported a complete lack of capture of bluefin tuna from the Tunisian trap of Sidi Daoud during excavation work in the Tunis harbour, as a result of increased turbidity in coastal waters due to high sediment levels. Negative effects were frequently recorded in Libyan traps during seasons with a strong Ghibli (wind from the southeast) that transports sand from the desert (Grassi 1913). Bluefin tuna are known to be very sensitive to sediments in coastal waters and high mortality has been recorded in the tuna farming industry as a result of high sediment levels in grow-out pens (Munday and 
Hallegraeff 1997). Lemos and Gomes (2004) substantiate this evidence in their report of the Portuguese trap at Barril, where longshore currents significantly reduce the odds of catching BFT on days of strong and persistent winds.

The second scenario that could explain the negative effect of strong winds on captures is related to the trap system, because a persistent strong Mistral may be a source of technical-distress on the system of nets that would provisionally reduce their capture efficiency. Possible alteration due to a shrinkage in the trap mouth may also inhibit, or reduce, the entrance of BFT into the chambers. Furthermore, an opposite effect could also be presumed, since strong currents might enlarge the trap mouth, allowing bluefin tuna to escape from the first chamber. Technical investigation would, however, be required to clarify this mechanism in order to ameliorate the catchability of the trap array.

Visual counts have proven to be useful because they throw more light on the occurrence of tuna schools in relation to the size structure of individuals (data not presented here). It emerged that smaller BFT schools tend to be more size-homogeneous. As school dimensions increased, there was a clear increase in size range. It is noteworthy that the assemblage of BFT with the sunfish, Mola mola, is concomitant with NW wind events. Although this phenomenon does not occur regularly, we have recorded large numbers of $M$. mola (up to a hundred) during some visual counts. These individuals frequently remained entangled in the trap nets, causing additional work for the professional trap divers who had to remove sunfish from the chambers or clean deceased specimens from nets. Although Mola mola is an active swimmer capable of highly directional movements independent of the prevailing current regime (Cartamil and Lowe 2004), this species can also accomplish passive drifting (Pope et al. 2010), which corroborates our hypothesis that BFT may opportunistically switch from active to passive swimming.

In conclusion, the results from this study show that bluefin tuna occurrence and abundance in Mediterranean trap fishery can be affected by the episodes of NW wind, but it may be of interest to continue such investigations so as to better understand whether this process is strictly related to swimming performance and/or to the trap array efficiency. Although the exact nature of this relationship is unclear, we have presented plausible mechanisms that explain the process.

Our intention in this paper was also to stimulate discussion and research about the relationship between the migratory behaviour of bluefin tuna schools and the abiotic environment, at a small spatial scale. Monitoring these processes can be useful for understanding the nature of trends in the fishery, so forecasts of behaviours may improve the status of the population.

Observation of fishermen was a starting point for testing a hypothesis and for performing an experiment in a field laboratory represented by the trap fishery. This investigation can be regarded as an adjunct value for this fishery, the last active trap fishery in the Mediterranean, emphasizing its role the scientific monitoring of this economically and ecologically important species.

\section{ACKNOWLEDGEMENTS}

We would like to thank to the Ligure Sarda Company (tonnara dell'Isola Piana), all tonnarotti fisherman, who provided logistical support in the period 2009-2010. We wish to express our gratitude to the diver team of the "Carloforte Tonnare Diving Centre" for their invaluable support during the visual census in the trap chambers. We thank the ICCAT secretariat and the ICCAT-GBYP coordinator for drawing attention to the issue of the trap fishery. We also appreciated the constructive criticism of two anonymous referees, which substantially improved the paper.

\section{REFERENCES}

Addis P., Dean J.M., Pesci P., Locci I., Cannas R., Corrias S., Cau A. 2008. Effects of local scale perturbations in the Atlantic bluefin tuna (Thunnus thynnus L.) trap fishery of Sardinia (W. Mediterranean). Fish. Res. 92: 242-254.

Addis P., Secci M., Locci I., Cau A., Sabatini A. 2012. Analysis of Atlantic bluefin tuna catches from the last Tonnara in the Mediterranean Sea: 1993-2010. Fish. Res. 127-128: 133-141.

Angotzi F. 1901. L'industria delle tonnare in Sardegna. Pongetti Editore, Bologna $116 \mathrm{pp}$.

Block B.A., Teo S.L.H., Walli A. 2005. Electronic tagging and population structure of Atlantic bluefin tuna. Nature 434: 1121-1127

Botsford L., Lawrence C.A., Dever E.P., Hastings A., Largier J. 2003. Wind strength and biological productivity in upwelling systems: an idealized study. Fish. Oceanogr. 12(4): 245-259.

Brito G. 1943. Pesca do Atum. Bol. Pesca 1(2): 2-82.

Brodersen J., Nilsson P.A., Ammitzbøll J., Hansson L.A., Skov C., Brönmark C. 2008. Optimal swimming speed in head currents and effects on distance movement of winter-migrating fish. PLoS ONE 3(5): e2156.

Carlsson J., McDowell J.R., Díaz-Jaimes P., Carlsson J.E.L., Boles S.B., Gold J.R., Graves J.E. 2004. Microsatellite and mitochondrial DNA analyses of Atlantic bluefin tuna (Thunnus thynnus thynnus) population structure in the Mediterranean Sea. Mol. Ecol. 13: 3345-3356.

Cartamil D.P., Lowe C.G. 2004. Diel movement patterns of ocean sunfish Mola mola off southern California. Mar. Ecol. Prog. Ser. 266: 245-253.

Chapman E.W., Jorgensen C., Lutcavage M.E. 2011. Atlantic bluefin tuna (Thunnus thynnus): a state-dependent energy allocation model for growth, maturation, and reproductive investment. Can. J. Fish. Aquat. Sci. 68: 1934-1951.

De Buen F. 1925. Biologia del atún (Orcynus thynnus L.). Result. de las camp. real. por acuerd. intern. 1. Comm. Int. Mer Médit., Madrid, $118 \mathrm{pp}$.

De Metrio G., Arnold G.P., de la Serna J.M., Block B.A., Megalofonou P., Lutcavage M., Oray I., Deflorio M. 2005. Movements of bluefin tuna (Thunnus thynnus L.) tagged in the Mediterranean Sea with pop-up satellite tags. Collect. Vol. Sci. Pap. ICCAT 58:1337-1340.

Donda F., Gordini E., Rebesco M., Pascucci V., Mosetti R.G., Lazzari P., Fontolan M. 2008. Shallow water sea-floor morphologies around Asinara Island (NW Sardinia, Italy). Cont. Shelf. Res. 28: 2550-2564.

Doumenge F. 1998. L'histoire des peches thonieres. Proceedings of the ICCAT tuna symposium. Collect. Vol. Sci. Pap. ICCAT Vol. $\mathrm{L}(2)$ : 753-803.

Fromentin J.M., Fonteneau A., Farrugio H. 2000. Biological key reference points and natural long-term fluctuations: the case 
of the Atlantic bluefin tuna. Collect. Vol. Sci. Pap. ICCAT, 51: 2072-2084

Grassi B. 1913. Conflitto tra le tonnare Porto Paglia e Portoscuso contro la Società Anonima Malfidano. Ed. Corsi e Ciarlo, Genova.

Korsmeyer K.E., Dewar H. 2001. Tuna metabolism and energetics. In: Block B.A., Stevens E.D. (eds.), Tuna. Physiology, Ecology, and Evolution. Academic Press, San Diego, CA, pp. 35-78.

ICCAT, 2012. ICCAT-GBYP Symposium on trap fisheries for bluefin tuna. Collect. Vol. Sci. Pap. ICCAT, 398 pp.

Lemos R.T., Gomes J.F. 2004. Do local environmental factors induce daily and yearly variability in bluefin tuna (Thunnus thynnus L.) trap catches? Ecol. Model. 177(1-2): 143-156.

Lozano Cabo F. 1958. Los Escómbridos de las aguas Españolas y Marroquíes y su pesca. Publ. Inst. Esp. Oceanogr. 25: 1-254.

McCullagh P., Nelder J.A. 1989. Generalized linear models. Second Edition. Chapman \& Hall, University Press, Cambridge, $511 \mathrm{pp}$.

Mather F.J., Mason Jr J.M., Jones A.C. 1995. Historical document: Life history and fisheries of Atlantic bluefin tuna. NOAA Technical Memorandum NMFS-SEFSC-370.

Mazzarelli G. 1917. Conflitto fra tonnare e miniere in Sardegna. Rivista di pesca e Idrobiologia Anno XI (XVIII) 4: 139-163.

Medina A., Abascal F.J., Megina C., Garcia A. 2002. Stereological assessment of the reproductive status of female Atlantic northern bluefin tuna during migration to Mediterranean spawning grounds through the Strait of Gibraltar. J. Fish. Biol. 60: 203-217.

Medina A., Cort J.L., Aranda G., Varela J.L., Aragon L., Abascal F. 2011. Summary of bluefin tuna tagging activities carried out between 2009 and 2010 in the eastern Atlantic and Mediterranean Sea. Collect. Vol. Sci. Pap. ICCAT 66(2): 874-882.

Millot C. 1999. Circulation in the Western Mediterranean sea. $J$. Mar. Syst. 20: 423-442.

Munday B.L., Hallegraeff G.M. 1997. Mass mortality of captive, southern bluefin tuna (Thunnus maccoyii) in April 1996 in Boston Bay, South Australia: a complex diagnostic problem. In: International Symposium on Diseases in Marine Aquaculture, Hiroshima, Japan

Neuparth A.E. 1923. Subsídios para o estudo dos peixes imigrantes nas nossas costas de Portugal. A Pesca Maritima 1: 24-26.

Pinardi N., Masetti E. 2000. Variability of the large scale general circulation of the Mediterranean Sea from observations and modelling: a review. Palaeogeogr. Palaeoclimatol. Palaeoecol. 158: 153-173.

Pope E.C., Hays G.G., Thys T.M., Doyle T.K., Sims N., Queroz N., Hobson V.J., Kubicek L., Houghton J.D.R. 2010. The biology and ecology of the ocean sunfish Mola mola: a review of current knowledge and future research perspectives. Rev. Fish Biol. Fish. 20: 471-487.

Ravier C., Fromentin J.M. 2004. Are the long-term fluctuations in
Atlantic bluefin tuna (Thunnus thynnus) population related to environmental changes? Fish. Oceanogr. 13: 145-160.

Ribotti A., Puillat I., Sorgente R., Natale S. 2004. Mesoscale circulation in the surface layer off the southern and western Sardinia island in 2000. Chem. Ecol. 20: 345-363.

Riccioni G. Landi M., Ferrara G., Milano I., Cariani A., Zane L., Sella M., Barbujani G., Tinti F. 2010. Spatio-temporal population structuring and genetic diversity retention in depleted Atlantic bluefin tuna of the Mediterranean Sea. Proc. Natl. Acad. Sci. USA 107: 2102-2107.

Robinson A.R., Leslie W.G., Theocharis A., Lascaratos A. 2001. Mediterranean Sea circulation. In: Thorpe S.A., Turekian K.K. (eds), Encyclopedia of Ocean Sciences. Academic Press, New York, pp 1689-1706.

Rodriguez-Roda J. 1964. Biologia del Atun, Thunnus thynnus (L.), de la costa sudatlantica de España. Inv. Pesq. 25: 33-146.

Rooker J.R., Secor D.H., De Metrio G., Schloesser R., Block B.A., Neilson J.D. 2008. Natal homing and connectivity in Atlantic bluefin tuna populations. Science 322: 742-744.

Rykaczewski R., Chekley M. 2008. Influence of ocean winds on the pelagic ecosystem in upwelling regions. Proc. Natl. Acad. Sci. USA 105: 1965-1970.

Santos L.F.R. 1989. A pesca do atum no Algarve. Publicações do Parque Natural da Ria Formosa, Faro, 91 pp.

Sarà R. 1980. La pêche du thon rouge au thonaire en Méditerranée. Collect. Vol. Sci. Pap. ICCAT, 11: 238-254.

Schneider J., Fernandez V., Hernandez-Garcia F. 2005. Leaking method approach to surface transport in the Mediterranean Sea from a numerical ocean model. J. Mar. Syst. 57: 111-126.

Sella M. 1929. Migrazioni e habitat del tonno (Thunnus thynnus L.) studiati col metodo degli ami, con osservazioni su l'accrescimento, sul regime delle tonnare ecc. Mem. R. Com. Talassograf. Ital. 156: 511-42.

Sloman K.A., Wilson R.W., Balshine S. 2006. Behaviour and Physiology of Fish. Elsevier Academic Press, San Diego.

Sorgente R., Drago A.F., Ribotti A. 2003. Seasonal variability in the central Mediterranean Sea circulation. Ann. Geophys. 21: 299-322.

Storai T., Zinzula L., Repetto S., Zuffa M., Morgan A., Mandelman J. 2011. Bycatch of large elasmobranchs in the traditional tuna traps (tonnare) of Sardinia from 1990 to 2009. Fish. Res. 109: 74-79.

Tudela S., Sainz Trápaga S., Cermeño P., Hidas E., Graupera E., Quílez-Badia G. 2011. Bluefin tuna migratory behavior in the western and central Mediterranean Sea revealed by electronic tags. Collect. Vol. Sci. Pap. ICCAT 66(3): 1157-1169.

Scient. ed.: J. Salat

Received February 13, 2013. Accepted May 9, 2013.

Published online July 26, 2013. 